
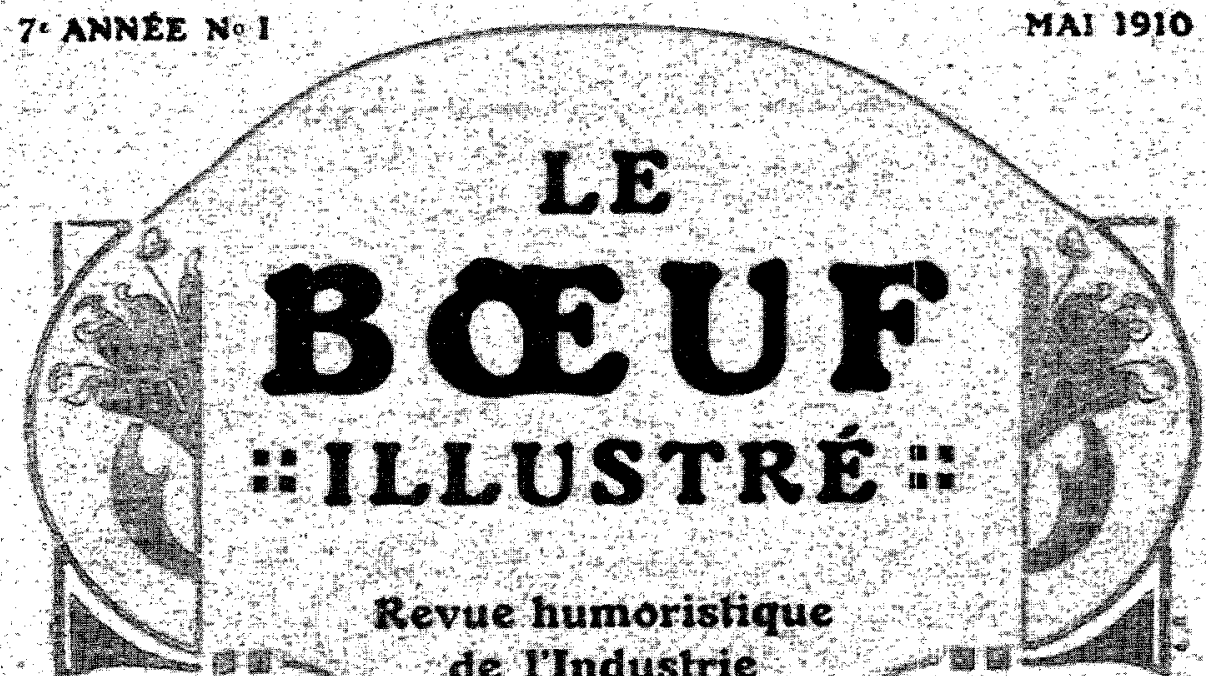

\title{
Revue humoristique
}

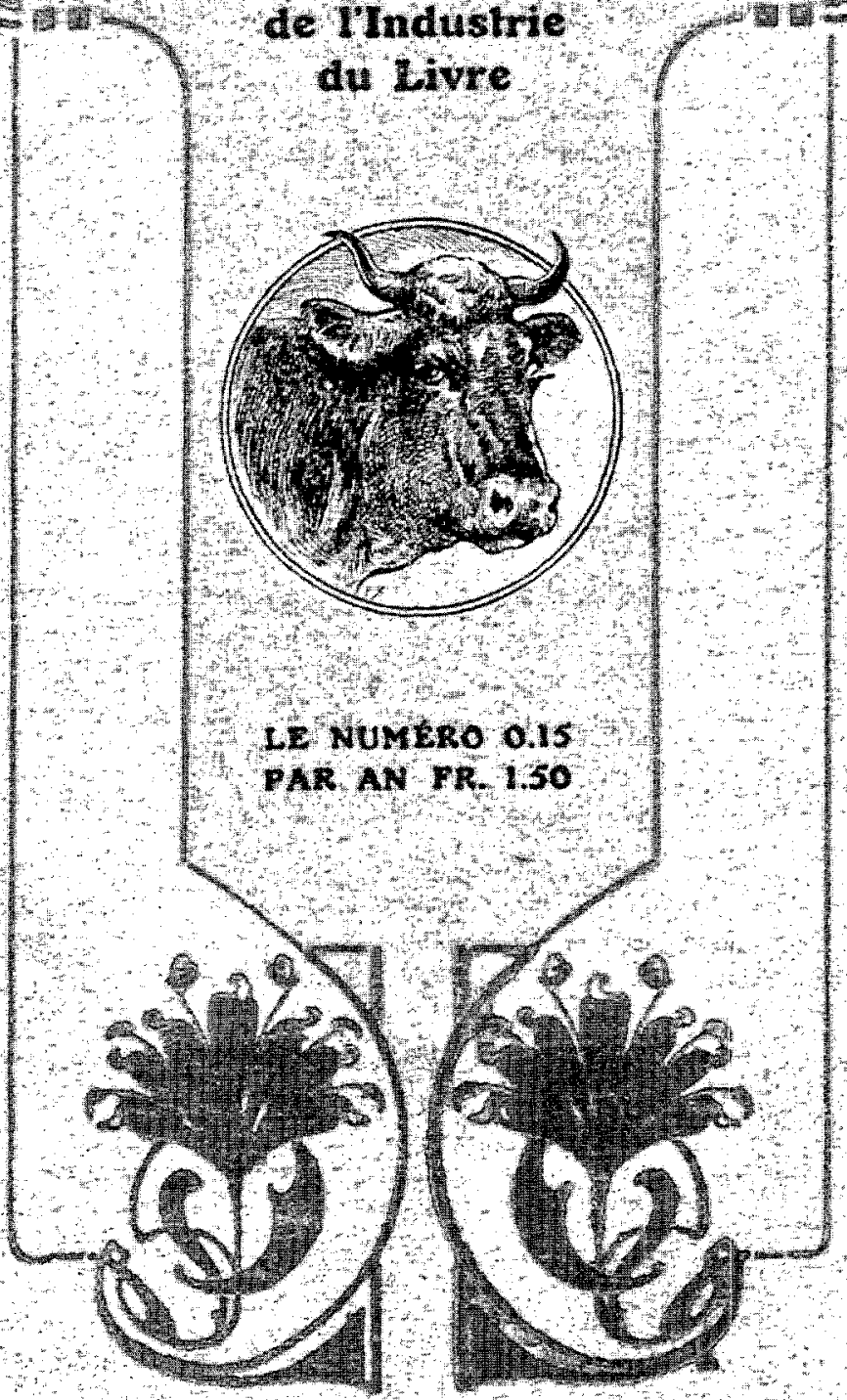




\section{Q De Brusselse typografen in de}

\section{hoofdstedelijke politieke arena in het laatste kwart van de 19 e eeuw ind}

Luc Peiren, Amsab

De Association Libre des Compositeurs et d'Imprimeurs Typographes de Bruxelles (ALCIT) werd in 1842 door de hoofdstedelijke typografen opgericht om de eigen lonen en arbeidsvoorwaarden te vrijwaren. Dit betrachtte de vakbond onder meer door een zo groot mogelijke controle op de lokale arbeidsmarkt te verwerven. Om haar leden eensgezind achter deze strategie te scharen, moest elke onenigheid vermeden worden. Mede daarom werd het bedrijuen van politiek in eigen rangen ten strengste bestreden. Dit nam echter niet weg dat de hoofdstedelijke typografenvakbondsleden zich wel ten individuelen titel in de politieke arena manifesteerden. Het zijn in hoofdzaak deze externe politieke uitingen die we in deze beknopte studie bekijken, alsook de politieke sollicitaties van de ALCIT en het 'politieke pluralisme' van haar leden.

\section{Inleiding}

Van bij haar ontstaan verankerde de ALCIT haar politieke neutraliteit in haar statuten: 'L'Association n'a et ne pourra jamais avoir, aucun but politique proprement dit. Fondée sous la protection des lois qui régissent le pays, l'Association, et en particulier chacun des membres qui la composent, s'engagent à prendre constamment pour règle invariable de conduite dans l'exercice des droits de tous, l'ordre, la légalité et la justice, en observant, et en invoquant toujours l'intégralité des intérêts communs, les strictes prescriptions de ces mêmes lois"(1) (artikel 2 van de statuten van de ALCIT van 1842). Dit apolitisme ging gepaard met een legalisme waarmee de vereniging de wetgever

Vorpagina van het satirische blad Le Boeuf Illustré uitgegeven door de Centrale van Boek en Papier 

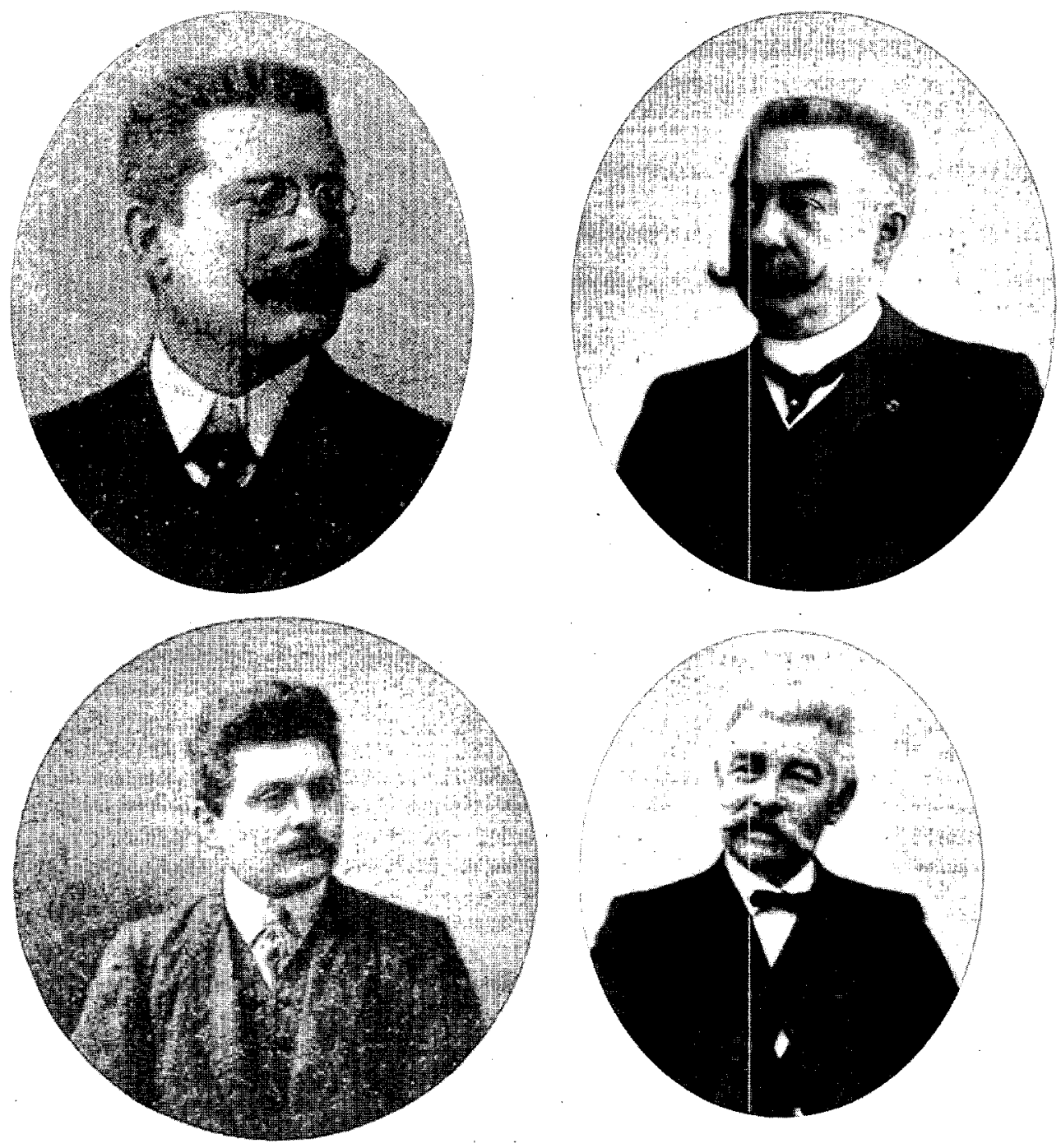

Désirê Vandendorpe, Jean Dumont, François Deklerck è Alfred Dufour, typografen en allen lid van de ALCIT 
vóór wou zijn want de grondwet proclameerde wel de vrijheid van vereniging, maar het strafwetboek verbood, vooral voor arbeiders "toute coalition (...) pour faire cesser de travailler" (2).

Om die redenen wees de ALCIT elke politieke avance af, wat niet eenvoudig was. Als succesvolle vakbond werd ze door alle politieke emanaties van de arbeidersbeweging gesolliciteerd. Vanaf 1859 was ze wel lid van de 'Association Générale Ouvrière' (AGO) die de pretentie had uit te groeien tot de koepel van alle Belgische arbeidersorganisaties. De AGO verenigde aanvankelijk zowel de Gentse textielsyndicaten als de Brusselse vakbonden. In Brussel zelf steunde de AGO ook op het democratische flamingantisme, het liberale progressisme en het arbeidersverzet tegen het coalitieverbod. In 1860 haakten de democratische flaminganten en de Gentse vakbonden echter af, waardoor de AGO terugviel op de Brusselse artisanale groepen ${ }^{(3)}$. Toen ze daarop al te nadrukkelijk bij de liberale partij ging aanleunen, trok de ALCIT zich uit de organisatie terug.

De linkerzijde van de Brusselse arbeidersbeweging betreurde in het proudhonistische blad La Tribune du Peuple de afwezigheid van de ALCIT "dans les questions philosophiques et politiques"(4). De Belgische afdeling van de Eerste Internationale trachtte tijdens de Brusselse typografenstaking van 1869 op haar beurt de ALCIT tot lidmaatschap te bewegen: "Vous avez pratiqué jusqu'ici la solidarité entre vous. Il s'agit d'élargir vos vues et de comprendre que cette solidarité doit embrasser tous les travailleurs, sans distinction de métier"(5). Veel ALCIT-leden waren al tot de Internationale toegetreden vanuit de verwachting dat ook hun vakbond dat zou doen ${ }^{(6)}$; hun voorzitter, Hendrik Kats, was reeds lid. De ALCIT was voor de Belgische afdeling van de Internationale van groot belang. Eens de oudste en meest gerenommeerde Brusselse vakbond ervoor gewonnen was, zouden andere Brusselse vakbonden volgen met het oog op "le rassemblement de toute la masse artisanale de Bruxelles et la transformation de cet ensemble hétérogène en une classe sociale, cohérente et organisée"(7).

De oproep was rechtstreeks gericht aan de ALCIT, die echter weigerde aan te sluiten op grond van artikel 2 van haar statuten, wat niet wil zeggen dat ze zich afsloot van de arbeidersbeweging. Op 7 februari 1869 werd het blad Grève des Typographes vervangen door een nieuw weekblad, La Presse Ouvrière, Organe des Associations en tout ce qui a rapport au bien-être du travailleur. Het wilde een spreekbuis zijn voor "tous nos confrères et amis, qui voudront s'occuper avec nous à préparer la solution du plus grand problème du siècle, nous dirons de tous les sièdles, l'émancipation et l'affranchissement des masses, l'amélioration matérielle, intellectuelle et morale $d u$ sort de la classe ouvrière"(8). Vanuit die optiek werd een rubriek Correspondances opgestart die openstond voor alle meningen.

De weigering zich als organisatie actief te engageren in de Internationale moet ook gezien worden in het teken van de mislukte Luikse typografenstaking van begin 1869. Volgens burgerlijke bladen was de Luikse vakbond tot staken aangespoord door de Belgische afdeling van de Eerste Internationale ${ }^{(9)}$; door die mislukking ging hij ten onder. Dit sterkte de ALCIT allicht in haar overtuiging afzijdig te blijven van de Inter- 
nationale: "N'abordons pas des questions qui seraient incompatibles avec nos vrais intérêts et qui, par la suite, pourraient amener notre ruine ${ }^{\prime \prime(10)}$.

Wat geenszins wilde zeggen dat de ALCIT zich nooit mengde in politieke kwesties, integendeel. In 1863 trad haar voorzitter, François Vanderslaghmolen, af als ondervoorzitter van de Brusselse werkrechtersraad omdat het parlement artikel 1781 van het burgerlijk wetboek (bij betwistingen werd de patroon steeds op zijn woord geloofd) niet had afgeschaft tijdens de discussies over de werkrechtersraden. Samen met twee andere hoofdstedelijke typografen zetelde hij in 1866 ook in het 'Comité central et permanent de propagande pour la réforme électorale' dat het capacitair stemrecht voor de arbeiders eiste.

\section{En Avant!}

In de jaren 1880 zou het probleem van dit apolitisme nog complexer worden met de opkomst van de sociaal-democratie. In Brussel moet die opkomst onder meer gezien worden in het kader van de hervorming van het cijnskiesrecht in 1883, dat een elite van arbeiders-kiezers onder bepaalde voorwaarden de kans gaf deel te nemen aan politieke verkiezingen. Deze evolutie had. ook invloed op de Brusselse vakbeweging in het algemeen en op de ALCIT in het bijzonder.

In 1881 werd de 'Ligue Nationale pour la Réforme Electorale' opgericht. De Brusselse afdeling ervan trachtte de arbeidersorganisaties te mobiliseren voor een herziening van de grondwet. Niet de ALCI'T zelf, maar een groot deel van haar militanten ( 417 op een totaal van 685) beantwoordde deze oproep. Zij richtten op 24 juli 1882 'En Avant! Ligue Typographique bruxelloise de la Réforme électorale' op, met Pierre Kaberghs als voorzitter en Jean Dumont als secretaris. Ook in Luik, Gent en Verviers richtten typografen kiesverenigingen op. In november 1882 eiste 'En Avant!' stemrecht voor elkeen die kon lezen en schrijven (capacitair stemrecht). De hervorming van het kiesrecht een jaar later kwam deels tegemoet aan deze eis. De wetgever verruimde het kiespubliek met 100.000 bekwaamheidskiezers (kiezers in het bezit van een diploma lager onderwijs; die een maatschappelijke functie bekleedden of slaagden in een kiesexamen). Deze kiezers konden maar één stem uitbrengen voor gemeente- en provincieraadsverkiezingen.

Tijdens de gemeenteraadsverkiezingen van 1884 werden in de Brusselse agglomeratie drie typografen, op een totaal van tien arbeiderskandidaten, op liberale lijsten verkozen: Emile Wittman en Victor Vandersteen, die zich later profileerden als liberaal en Joseph Sommer die enkele jaren later zelf werkgever werd ${ }^{(11)}$.

Hier situeert zich een eerste pijnpunt in de relatie tussen ALCIT en 'En Avant!' en de opkomende politieke socialistische beweging, want niet alle leden van de vakbond en 
de kiesvereniging hingen het socialisme aan alleen maar omdat zij arbeider waren. Een groep leden bekende zich duidelijk tot het (progressief) liberalisme, een optie die ook andere vakgroepen in de Brusselse agglomeratie kenmerkte. In 1884 werd de schilder Alphonse Vandenhouten, gewezen Belgische correspondent van de Eerste Internationale, verkozen als progressief liberaal gemeenteraadslid. Bij de Brusselse typografen was deze optie des te opvallender door hun grote participatie aan verschillende verkiezingen, hetzij als socialist, hetzij als arbeiderskandidaat op liberale en later zelfs katholieke lijsten.

Deze diversiteit van politieke opties werd hen door de georganiseerde socialistische beweging niet in dank afgenomen. Bij de gemeenteraadsverkiezingen van 1884 stelde La Voix de l'Ouvrier (orgaan van de arbeidersbonden van de Brusselse agglomeratie) 'En Avant!' aan de kaak, nadat haar voorzitter, Dumont, een aanbod had afgeslagen om op een socialistische lijst te staan: “Elle (En Avant!) n'a plus qu'une existence éphémère. Ses membres les plus résolus et les plus sincères sont entrés à la Ligue Ouvrière. La Ligue En Avant! ne sort plus de sa tombe que quand cela convient à son fantaisiste président. Le comité de la Ligue n'est rien: on ne le convoque point.(...) Cette société trop fière pour faire cause commune avec la masse des travailleurs, n'a donc plus aucune autorité, même morale, surles ouvriers"(12).

'En Avant!' weigerde in 1884 ook lid te worden van de Federatie van Brusselse arbeidersliga's. Voix-redacteur Louis Bertrand noemde de organisatie daarna de 'Ligue En Arrière!'(13) Dumont antwoordde door erop te wijzen dat 'En Avant!' in oktober 1884 nog steeds 275 leden telde en nog altijd actief was. Maar het was wel zo dat een aantal belangrijke vakbondsleden en -functionarissen zich intussen volop engageerde in de Federatie van Brusselse arbeidersliga's en de Brusselse arbeidersliga. Deze laatste werd zelfs geleid door typografen die er de voorzitter en de twee secretarissen voor leverden ${ }^{(14)}$. Later kregen de socialisten meer greep op 'En Avant!' De liga nam deel aan het stichtingscongres van de BWP op 5 en 6 april 1885 . Op 5 september 1885 besloot ze bij de BWP aan te sluiten en benoemde ze afgevaardigden in de federale raad van de Brusselse BWP-federatie. Eén jaar later keurde ze de deelname aan de BWP-betoging van 15 augustus 1886 ten voordele van het algemeen stemrecht goed. Op 12 december 1886 werd de socialistische typograaf Désiré Vandendorpe verkozen in de Brusselse gemeenteraad ${ }^{(15)}$.

Tot 1897 nam het aantal typografen in de leidende organen van de BWP en haar Brusselse federatie toe. In eerste instantie in het Bureau van de Algemene Raad, toen gemakshalve enkel uit Brusselaars samengesteld. In 1887 waren twee typografen lid van dit zeskoppig bureau; tussen 1891 en 1895 waren vier typografen lid van het Bureau van de Algemene Raad, dat toen uit acht man bestond. 


\section{SYNDIKALE KOMMISSIE}

DER

WERKLIEDENPARTIJ

EN DER

Onafhankelijke Vakbonden

$\rightarrow=0$

'SEKRHTARLAR'?':

VOIES EI UIS

(180 VERDIEP, ZAAL 13)

17, Jozef-Stevensistraat

B $\mathrm{FUEBDI}$ -

$\sqrt{46^{2}}$

Brussel, postdatum.

\title{
Aan de aangesloten Vakvereenigingen!
}

\author{
Stamaraden.
}

Wij hebben het genoegen $u$ te herinneren dat de bijdrage bij de Herverzekeringskas voor werkstakingen en lock outs, gevestigd in den schoot der Syndikale Kommissie der Werkliedenpartij en Onafhankelijke Vakbonden, verplichtend geworden is van af den $1^{\text {sten }}$ Januari 1911 voor al de vakbonden bij de Syndikale Kommissie aangesloten.

De nationale vakfederaties en beroepscentralen alsook de vakvereenigingen die nog niet gecentraliseerd noch gefedereerd zijn, worden dus uitgenoodigd regelmatig het beloop der bijdragen $(5$ centiemen per lid en per maandi op te zenden aan den Schatbewaarder : gezel Pieter Lalemand, 20. Willebroeckskaai, Brussel.

Wif herinneren $\mathrm{u}$ ook dat het Kongres van $25^{\mathrm{a}}$ en $26^{\mathrm{i}}$ December 1910 besloten heeft dat de bijdragen aan de Syndikale Kommissie voor 1911 in dent loop van den $1^{\text {sem }}$ trimester dezes. 't is te zeggen, ten laatste den $31^{\text {th }}$ Maant 1911 moeten opgezonden worden aan omzen hoogergenoemden schatbewaarder.

Wij houden er ook aan $u$ te doen opmerken dat het beșluit, de bondsbesturen te abonneeren aan het Korrespondentieblad. genomen op het Kongres van $25 \cdot 26^{\mathrm{n}}$ December 1909 , hernieuwd is geworden en dat het Kongres van 25-26" December 1910 besloten heeft de namen der bonden in ons blad mede te deelen welke in den loop van den $1^{\text {taten }}$ trimester dezes jaar, zich niet voor minstens 7 abonnementen ingeschreven hebben

Wij bidden de bestuurleden der geabomeerde bonden, die niet regelmatig het Korrespondentieblad ontvangen, eene schriftelijke klacht neer te leggen bij den postontvanger hunner gemeente. Het is eenen raad die voor het opzenden van het Korrespondentieblad, niet moet uit het ong verloren worden.

Wij raden de aangesloten vakbonden bijzonder aan goede nota te willen nemen van dezen omzendbrief en bidden hun onze broederlijke groeten te willen aanvaarden.

\section{Voor de Syndikale Kommissie :}

het BuReEl : Baeck Jozef, Conrardy Gustaaf, Lalemand Pieter, Neukens Antony, Solat. Hillem, Theunissens Alexandfr, Bergmans Jan, schrijver; Afgevaardigden aan den Landelijken Rada : Huysmans Kameh, VanderSMISSEN LAURENT.

N. B. - Wij verzoeken insgelijks de vakvereenigingen voort te gaan met het inzamelen def gedden, door omhalingen op de werkhtuizen te doen, en toelagen te stemmen voor de stakingen.

Deze sommen moeten gestuurd worden aan J.Bergmans, Volkshuis, Jozef-Stevensstraat, Brussel.

Vanaf 1900 verminderde het aantal typografen in de politieke organen van de BWP maar permeerderde hun aanwezigheid in het Bureau van de Syndikale Kommissie. In dit pamflet van de Syndikale Kommissie zijn drie van de zeven leden van het Bureau typografen, namelijk $G$. Conrardy, A. Theunissens en J. Bergmans 


\section{De Brusselse typografen en hun electorale successen}

In 1887 werden drie typografen verkozen als gemeenteraadslid. In Brussel werd Désiré Vandendorpe herkozen op een progessief-liberaal-socialistische lijst en Pierre Kaberghs op een doctrinair-liberale ${ }^{(16)}$. Vandersteene werd herkozen in Sint-Joostten-Noode. In 1890 waren vijf typografen kandidaat voor de gemeenteraadsverkiezingen in de Brusselse agglomeratie, op een totaal van zestien kandidaten. Drie van hen werden verkozen op een totaal van elf gekozenen (allen op liberale lijsten); Wittman als liberaal voor Schaarbeek ${ }^{(17)}$; met Jules Vanderlinden voor Laken leverden de typografen in 1893 de eerste socialistische schepen van de Brusselse agglomeratie ${ }^{(18)}$.

Datzelfde jaar organiseerde de BWP een staking voor het algemeen stemrecht. De liga 'En Avant!' steunde de staking die aan de basis lag van de grondwetsherziening die het algemeen meervoudig stemrecht invoerde en participeerde nadien actief in de BWPpropaganda naar aanleiding van de parlementsverkiezingen van $1894^{(19)}$. In Brussel kreeg de BWP zelf onvoldoende stemmen om verkozenen te halen. Een aantal Brusselaars liet zich elders verkiezen, zoals gewezen ALCIT-secretaris en Belgische Typografische Federatie (BTF)-voorzitter Gustave Defnet, die opkwam in zijn geboorteplaats Namen.

De verkiezing van Charles Mousset op de katholieke lijst van Brussel verdween tussen de plooien van de geschiedenis. Mousset was enerzijds lid en in 1895-1896 secretaris van de ALCIT, maar anderzijds ook voorzitter van 'Concordia-Maison des Ouvriers' te Brussel, die aan de basis lag van de ontwikkeling van de christen-democratische arbeidersbeweging aldaar.

In 1895 kregen de arbeiders ook stemrecht voor de gemeenteraadsverkiezingen. Het werd echter ingeperkt door een aantal voorwaarden (dertig jaar oud zijn, domiciliëringsplicht van drie jaar...). Arbeiders en patroons mochten in de grote steden echter wel bijkomende gemeenteraadsleden kiezen. De typografen hadden op BWP-lijsten zeventien kandidaten in de Brusselse agglomeratie. Vier werden verkozen op een totaal van tweeënveertig socialistische gekozenen ${ }^{(20)}$ : Désiré Vandendorpe, Jan Bergmans, Gustave Conrardy en Camille Hody. Twee andere typografen, $\mathrm{W}_{1}$ ttman en Vandersteene, werden herkozen als liberaal raadslid.

In 1896 kende de ALCIT haar 'politieke hoogtepunt'. Vijf gewezen ALCIT-leiders (Gustave Defnet, Georges Maes, Antoine Delporte, Désiré Vandendorpe en Romain Van Loo) zetelden in het Bureau van de Algemene Raad van de BWP dat toen uit negen man bestond. Tijdens de parlementsverkiezingen van 5 en 12 juni 1896 dongen drie gewezen vakbondsfunctionarissen op evenveel lijsten naar de gunst van de kiezer: secretaris Mousset op de katholieke lijst, bestendig afgevaardigde Alfred Dufour voor de doctrinair liberalen en ondervoorzitter Antoine Delporte voor de radico-socialististen. Op de katholieke lijst stond nog een typograaf die geen ALCIT-lid was, met name uittredend kamerlid Henri Colfs; op de liberale lijst stond Léon Hendrickx, eveneens typograaf maar geen vakbondslid. Aangezien de katholieke lijst te Brussel 
zegevierde, werden Mousset en Colfs herkozen. In het parlement zetelden zij samen met Defnet.

In de periode 1894 -1896 had de ALCIT een katholieke en een socialistische volksvertegenwoordiger, liberale en socialistische gemeenteraadsleden en een niet te onderschatten vertegenwoordiging in het Bureau van de Algemene Raad van de BWP, een politieke machtspositie die samenviel met een voor háar nog belangrijker evolutie. Door geslaagde stakingen in 1890 en 1896 in de werkhuizen die het vakbondstarief (loon) niet erkenden, wist ze een nog grote groep niet-gesyndiceerden te rekruteren en zodoende, net voor de eeuwwisseling, een nagenoeg sluitende situatie te realiseren, en waren de ledentallen van de vakbond gestegen van 696 in 1886 over 1068 in 1891 tot 1394 in 1897. Van alle Brusselse vakbonden was de ALCIT daardoor de grootste. Hoewel ze niet rechtstreeks bij de Brusselse BWP-federatie was aangesloten, had ze er toch banden mee via de lokale federatie van grafische beroepen (de 'Fédération Locale de l'Industrie du Livre'), opgericht in 1896, die wel bij de BWP en de Syndikale Kommissie was aangesloten, en via 'En Avant!' die qua ledentallen lange tijd kon concurreren met de gemeentelijke arbeidersliga's. Dankzij de grootte van de vakbond waren de typografen op gemeentelijk vlak ook nog steeds geschikte 'arbeiderskandidaten' voor de overige partijen.

\section{De tanende politieke invloed van de ALCIT in het begin van de 20e eeuw}

Het is zeer opvallend dat toen het aantal typografen in de politieke organen van de BWP verminderde, dit vanaf 1898 en vooral na 1900 gecompenseerd werd door een grotere aanwezigheid in de syndicale structuren van de BWP. In het Bureau van de Syndikale Kommissie zetelden tussen 1907 en 1913 vier typografen op een totaal van negen leden. Daarbij moet er wel op gewezen worden dat de Syndikale Kommissie zich gaandeweg meer afficheerde als een overkoepelend orgaan van socialistische én neutrale vakbonden.

Maar dat wil niet zeggen dat de politieke invloed van de typografen eensklaps verminderde. In 1900 werd het algemeen meervoudig stemrecht geamendeerd door de evenredige vertegenwoordiging, waardoor Vlaanderen en Brussel voor het eerst hun eigen volksvertegenwoordigers leverden. In 1900 werd Antoine Delporte verkozen als socialistisch volksvertegenwoordiger voor Brussel. Daarnaast verminderde inderdaad het aantal typografen in het geheel van de gemeenteraden van de Brusselse agglomeratie, maar ze bleven kwalitatief sterk aanwezig in de afzonderlijke gemeenteraden van Brussel en Sint-Gillis. In verband met de gemeentelijke subsidiëring van de werkloosheidskassen van vakbonden in de Brusselse agglomeratie was dit niet onbelangrijk, aangezien de stad Brussel aanvankelijk eigenzinnig een eigen werkloosheidskas inrichtte, naast de intercommunale kas die vooral door Sint-Gillis gepromoot werd ${ }^{(21)}$. 
Eveneens opvallend is dat de typografen na 1900 grotendeels enkel nog binnen de BWP politiek actief waren. Moussets politieke mandaat eindigde in 1900 en hij werd in de katholieke partij niet door een andere typograaf vervangen. De typografische vertegenwoordiging in de liberale partij bleef na 1896 beperkt tot het Schaarbeekse gemeenteraadslid Wittman (die in 1907 zijn mandaat als gemeenteraadslid, op basis van een kartelafspraak, afstond aan BWP-coryfee Louis Bertrand, die anders zijn schepenmandaat had moeten inleveren ${ }^{(22)}$ ) en Vandersteene te Sint-Joost-ten-Noode.

Dit betekent ook niet dat de ALCIT alleen nog maar socialistische aanhangers telde, of zich nog enkel door hen liet leiden, integendeel. Tijdens en na de staking van 1900 was een katholiek, François Drion, secretaris van de ALCIT terwijl Alfred Dufour (in 1896 liberaal kandidaat-volksvertegenwoordiger voor de liberale partij) tot 1908 de enige bezoldigde functionaris van de vakbond was. Aangezien elke functie binnen de ALCIT jaarlijks hernieuwd diende te worden via verkiezingen, betekent dit dat ofwel beide politieke tendensen alsnog invloed hadden op de vakbond, ofwel dat deze functionarissen op basis van hun merites werden (her)verkozen, of dat beide factoren golden. Het gold in elk geval voor François Deklerck die tussen 1910 en 1912 voorzitter was van de ALCIT. In zijn monografie uit 1904 over de typografie te Brussel, bevestigt Perquy dit beeld. Hij meent dat de hoofdstedelijke typografen in groten getale socialist waren. Hun socialisme was echter niet doorleefd. Zij waren zeker geen aanhangers van het collectivisme. Zij zagen in de BWP vooral de partij van de arbeiders. Daartegenover hielden de burgerpartijen zich enkel met de sociale kwestie bezig uit eigenbelang en wegens hun angst voor de socialisten ${ }^{(23)}$.

Dit verklaart mee waarom het (progressief) liberalisme van halfweg de jaren 1880 tot halfweg de jaren 1890 voor veel typografen een politieke optie was. Daarna diende de BWP zich als een volwassen partij aan met een wetgevende vertegenwoordiging op gemeentelijk, provinciaal en nationaal niveau en uitvoerende macht op gemeentelijk en provinciaal niveau.

De keuze van vele typografen voor het socialisme had ook veel te maken met de introductie van de zetmachine rond de eeuwwisseling, waardoor de machtsverhoudingen in de sociale relaties in het voordeel van de werkgevers dreigden te kantelen. In 1900 staakte de vakbond ruim een maand, om naar het voorbeeld van de buitenlandse vakbonden de bediening van de zetmachines voor haar leden te claimen en via arbeidsduurvermindering de nefaste gevolgen van deze technologische innovatie voor de werkgelegenheid te milderen. Gedurende deze succesvolle staking kreeg de ALCIT een ernstige waarschuwing van de werkgeversorganisatie die de eis voor arbeidsduurvermindering interpreteerde als een politieke (zeg socialistische) eis, hetgeen voor haar een reden was om de ALCIT niet langer als (enige) arbeidersorganisatie te erkennen. Ook omdat de werkgevers nadien een eigen mutualiteit oprichtten voor arbeiders die niet langer akkoord gingen met de 'politieke actie' van de vakbond, gedroeg de ALCIT zich op dit terrein na 1900 nog voorzichtiger. Getuige daarvan haar niet-participatie aan de algemene stakingen voor het algemeen stemrecht van 1902 en 1913. 
(1) Association libre des Compositeurs-Typographes de Bruxelles. Fondée en janvier 1842. Concorde-UnionConfraternité. Statuts, Bruxelles, Année 1846. Amsab, Verenigd Syndicaat van Boek en Papier van Brussel, 250/1.2.

(2) Association libre des Compositeurs-Typographes de Bruxelles. Fondée en janvier 1842. Concorde-UnionConfraternité. Statuts, Bruxelles, Année 1846. Amsab, Verenigd Syndicaat van Boek en Papier van Brussel, 250/1.2.

(3) J.-P. MAHOUX, I. PUISSANT, Les milieux familiaux et sociaux dans leur contexte bruxellois. In: Cahiers Marxistes, (octobre-novembre 19991213, p. 27.

(4) La Tribune du Peuple, 08.03.1863.

(5) Aux Typographes. In: L'Internationale, 17.01.1869.

(6) Brief van César De Paepe aan Hermann lung van 7 januari 1869. gepubliceerd in: Documents relatifs aux militants beiges de I'Association Internationale des Travailleurs. Correspondance 1865-1872. Textes réunis, élablis et annotés par Daisy Eveline Devreese. En collaboration avec Internationaal Instituut voor Sociale Geschiedenis, Leuven-Brussel: Uitgeverij Nauwelaerts, 1986, pp. 108, 125.

(7) H. COLLIN-DAICH, Contribution à l'élude de la Première Internationale à Bruxelles (1865-1873). In: Cahiers Bruxellois, avril-juin 1956, p. 131.

(8) A nos lecteurs. In: La Presse Ouvrière, 07.02.1869.

(9) La grève des typographes de Liège. In: La Presse Ouvière, 07.03.1869.

(10) E. HUBERT, Historieue de l'Association Libre des Compositeurs \& Imprimeurs Typographes de Bruxelles, Bruxelles: P. Weissenbruch, 1982.

(11) Chronique électorale. In: La Wix de /Oouvier, 19.10.1884.

(12) Des lâcheurs! In: La Voix de /Ouvrier, 12.10.1884.

(13) Correspondances. In: La. Wix de /Ouwier. 19.10.1884.

(14) R. ABS, Hisioire des fédérations 1885-1985, Bruxelles: PAC, 1985, p. 16.

(15) La Voix de IOOunier, 12.04.1885; La Voix de /Ouvrier, 13.09.1885; Le Peuple, 15.08.1886: Le Peuple, 13.12.1886.

(16) Le Peuple, 17.10.1887; Kaberghs werd hierna overigens uitgesloten als lid van 'En Avant!' terwij] hij op dat ogenblik nochtans voorzitter van de ALCIT was.

(17) Le Peuple, 19.10.1890; Woruit, 21 en 27.10.1890.

(18) Le Peuple, 15.06.1893. Dit gebeurde na een herverkiezing te Laken waarbij ook de typograaf FrançoisDenis Lesnino (gewezen adjunct-secretaris van de ALCIT) verkozen werd. Lesnino was het eerste BWP-lid dat door een Brusselse gemeenteraad verkozen werd om deel uit te maken van de commissie van burgerlijke ziekenhuizen van Laken. Hij werd later liberaal provincieraadslid. Zie daarvoor Le Peuple, 03.09.1891.

(19) Le Peuple, 09.06.1890. Het viel op dat Concordia in de afdeling 'Imprimerie' geen eigen lijst indiende; Le Peuple, 16.04.1893; Le Peuple, 28.09.1893.

(20) Le Peuple. 20.11.1895.

(21) Zie daarvoor G. CONRARDY, Histoire de la fédération locale, Bruxelles: Etablissements Généraux d'Imprimerie. 1921, pp. 173-180 en 332.

(22) Nécrologie. Le Père Wittmann. In: LAvenir de Schaerbeek, 19.03.1911.

(23) I.-L. M. PERQUY, La Typographie à Bruxelles au début du XXe siècle, Bruxelles: Oscar Schepens \& Cie, Editeurs, 1904 , pp. 283-284. 


\section{Bibliografie}

- R: BLANPAIN. De syndikale wijheid in België. Antwerpen-Amsterdam: Standaard-Boekhandel, 1963, 94 p.

- G. CONRARDY, Histoire de la Fédération locale. Bruxelles: Etablissements Généraux d'Imprimerie, 1921, 516 p.

- 1. DE BOE, 1842-1952. Un siècle de Iuttes syndicales, Bruxelles: Syndicat Unifié du Livre et Papier, 1952, $266 \mathrm{p}$.

- D. E. DEVREESE, Ambachten, arbeidsmarkt en arbeidersbeweging. Vorming van de moderne arbeidersbeweging te Brussel, 1842-I867. In: B. DE VRIES, E. NIJHOF, L. HEERMA VAN VOSS, M. PRAK en W. VAN DEN BROEKE, De Kracht der Zwakken. Studies over arbeid en arbeidersbeweging in het verleden. Opstellen aangeboden aan Theo van Tijn bij zijn afscheid als hoogleraar Economische en Sociale Geschiedenis aan de Rijksuniversiteit Utrecht, Amsterdam: Stichting bẹheer IISG, 1995.

- E. GUBIN, I.-P. MAHOUX, I. PUISSANT. Question sociale et libéralisme. L'exemple de I'Association Générale Ouvrière (1858-1920). In: A. VERHULST, L. PAREYN, Huldeboek Prof. Dr. Marcel Bots. Een bundel wijsgerige opstellen, Gent: Liberaal Archief, 1995, pP. 139-165.

- E. HUBERT, Historique de I'Association Libre des Compositeurs \& Imprimeurs Typographes de Bruxelles, Bruxelles: P. Weissenbruch, 1892, 372 p.

- G. KWANTEN, De Pletinckxstraat. Een eeuw sociale strijd in en rond Brussel, Leuven: ACW Brussel-HalleVilvoorde/KADOC, 1985, $176 \mathrm{p}$

- L. PEIREN, 100 jaar socialistisch municipalisme in België. De Belgische Werkliedenpartij (BWP) en de gemeenteraadsverkiezingen van 1895. In: AMSAB-Tijdingen, (1995)28, pp. 3-5.

-L. PEIREN, De Brusselse arbeidersliga's als voorlopers en stichtende componenten van de Belgische Werkliedenpartij (1 884-1886). In: AMSAB-Tijdingen. (1994) Nieuwe reeks, 24, pp. 3-9.

- I.-L.-M. PERQUY, La lypographie à Bruxelles au début du XX e siècle, Bruxelles: Oscar Schepens \& Cie., 1904. $253+122 \mathrm{p}$.

- M. SZTIENDERG, La fondation du parti ouvrier belge et le ralliement de la classe ouvrière à l'action politique 1882-1886. In: International Review on Social Hisiory, (1963)8, pp. 198-215.

- R. VALCKE, De Brusselse 'typograven' in de 1 gde eeuw. Een voorbereidende studie, VUB, licentiaatsverhandeling. 1986. $77 \mathrm{p}$.

- E. VANDERVELDE, Enquête sur les associations professionnelles d'artisans et ouvriers en Belgique, Bruxelles: Imprimerie des Travaux Publics, 1891, tome 1.

- S. en B. WEBB, Theorie en practijk van het Britsche vakvereenigingswezen, Amsterdam: Soep, 1901, 418 p.

- H. WOUTERS, Documenten betreffende de geschiedenis der arbeidersbeweging ten tijde van de le internationale (/866-1880); Leuven-Parijs: Nauwelaerts, 1970, deel 1. 